\title{
TREE COMMUNITY STRUCTURE AND ABOVEGROUND CARBON STOCK OF SACRED FOREST IN PASAMAN, WEST SUMATERA
}

\author{
SANTHYAMI ${ }^{1 *}$, ADI BASUKRIADI ${ }^{2}$, MUFTI PETALA PATRIA² AND ROCHADI ABDULHADI ${ }^{3}$ \\ 'Department of Biology Education, Faculty of Teacher Training and Education, Universitas Mubammadiyab Surakarta, \\ Sukobarjo 57162, Indonesia \\ ${ }^{2}$ Department of Biology, Faculty of Mathematics and Natural Sciences, Universitas Indonesia., Depok 16424, Indonesia \\ ${ }^{3}$ Division of Botany, Herbarium Bogoriense, Research Center for Biology, Lembaga Ilmu Pengetabuan Indonesia, Bogor 16911, Indonesia
}

Received 20 August 2020 /Accepted 7 September 2021

\begin{abstract}
This is an analysis of the composition and structure of tree community of Bukit Badindiang sacred forest in Nagari Simpang, Pasaman, West Sumatera Province, Indonesia. The study aimed to: 1 , to obtain a representative account of the structure and composition of tree community of the sacred forest; 2 . to estimate the Aboveground Carbon Stock (C-Stock) accumulated on the tree community. A one-hectare plot was divided into 25 subplots of $20 \times 20 \mathrm{~m}$ each for tree and debris data collection. In each subplots, there were a $5 \times 5 \mathrm{~m}$ sapling subplots. Planting of $1 \times 1 \mathrm{~m}$ seedling, understorey plant and litter subplots were nested inside. A total of 446 trees were recorded, representing 139 species from 49 families with a total basal area of $38.59 \mathrm{~m}^{2}$. The most dominant tree species was Campnosperma auriculata [Importance Value (IV) of 19.19]. The other prevalent species were Ficus benjamina (IV $=16.50)$ and Mallotus caudatus (IV =14.78). A total of 62 species $(44.6 \%)$ was considered locally rare with density of 1 tree/ha. Mallotus caudatus had the highest density ( 37 trees/ha) and Ficus benjamina had the highest Basal Area (BA) $\left(5.61 \mathrm{~m}^{2}=14.51 \%\right.$ of the total). Euphorbiaceae (IV= 37.40) was the dominant family. The richest families were Euphorbiaceae (10) and Lauraceae (10). The total estimated Aboveground C-Stock was $190.62 \mathrm{MgC} / \mathrm{ha}$, with the highest $\mathrm{C}$ was contributed by trees $(178.85 \mathrm{MgC} / \mathrm{ha}$ or $93.8 \%$ of total). Trees with diameter class of $10-69.99 \mathrm{~cm}$ stored $62 \%$ of total tree carbon. The species richness, tree density and C-Stock of Bakit Badindiang sacred forest were relatively higher than those in several disturbed lowland forests in Sumatera.
\end{abstract}

Keywords: carbon stock, community structure, sacred forest, tree species diversity, West Sumatera

\section{INTRODUCTION}

Local wisdom has always been involved in preserving biodiversity in Indonesia, shown in numerous forms such as sacred forest (butan larangan) (Wadley \& Colfer 2004), cultural landscape (Christiawan 2015) and traditional harvesting right (Boedhihartono 2017). West Sumatera Province is among regions in Indonesia in which sacred forest is still practiced. This paper will enlighten the potential of Bukit Badindiang sacred forest, a customary forest (butan adat) of Nagari Simpang, Simpang Alahan Mati (Simpati) District, Pasaman Region in West Sumatera Province, Indonesia.

"Corresponding author, email: san915@ums.ac.id
Sacred forest is one of the oldest forms of natural forest conservation by traditional community. Generally, sacred forest is a part of the natural forest ecosystem with high level of trees and animals diversity. In some cases, some prominent features such as water spring, fountain, and even oldest tree could be found in a sacred forest. They provide habitats and space for infrequent and threatened species of trees and animals and have a vital conservation value despite of their characteristically small areas (Boraiah et al. 2001). Some scholars have studied the link between 'the sacred' and biodiversity preservation of natural forests all over the world (Negi 2015; Allendorf et al. 2013; Ormsby et al. 2010). For instance, sacred groves become a refuge spot for mammals, birds, plants, and 
other forest-dwelling animals (Basu 2000; Chandran \& Hughes 1997; Sinha 1995). Sacred forest is also considered as carbon sink (Pradhan et al. 2016; Pala et al. 2012). On the contrary, local community also depends on sacred forest for various products used in daily life (Burman 2003).

The aims of this study were: 1 . to obtain the fundamental descriptive account of floristic structure and composition of Bukit Badindiang sacred forest under the management of customary law in Nagari Simpang, Simpati District, Pasaman, West Sumatera Province in conserving tree species diversity and 2. to estimate the capacity of sequestering carbon. An improved knowledge of basic ecological data, including floristic composition and C-stock potential of the forest is required for the development of natural ecosystem conservation and forest management. To date, there are relatively few detailed descriptions and quantitative assessments and estimation of customary and sacred forest floristic and Cstock in Indonesia (Indrajaya 2013; BPK 2012; Soendjoto et al. 2009).

Bukit Badindiang is one of the forested areas in Pasaman known as 'walled hill' as collecting timber from this site is restricted. Bukit Badindiang belongs to Koto Tribe who establishes this forest as 'sacred' area as the water fountain, a source of clean water for the whole village, is located in this forest. Sacred means: 1. Public (outside of Koto members) may only collect non-timber forest products such as firewood, fruits, honey, medicine, and resin; 2 . Timber can only be harvested by or as the permission of Koto leader for the community mosque construction and emergency needs; 3. Not to fell 'kayu tungga babeleang' means it was forbidden to cut down the low abundance trees.

Analysis of species inventory data collected in a one-hectare plot in this paper will be limited to the representation of the forest with reference to the key structural parameters such as pattern of relative abundance, species richness, and family structure and estimated Aboveground C-Stock.

\section{MATERIALS AND METHODS}

\section{Sampling Location and Sampling}

Sampling was carried out in Simpati District, located at $100^{\circ} 08^{\prime}-100^{\circ} 12^{\prime} \mathrm{E}$ and $00^{\circ} 04^{\prime} \mathrm{N}$ $00^{\circ} 03^{\prime} \mathrm{S}$ with an altitude of $100-890 \mathrm{~m}$ above sea level (Fig. 1). The topography of Nagari Simpang is a plain land surrounded by hills of natural forest. Temperature ranges from 27 $30{ }^{\circ} \mathrm{C}$ with a mean annual rainfall of 3,891 $\mathrm{mm} /$ year. Nagari Simpang is situated in the wet region belonging to the rainfall type $A$ climatically (Schmidt \& Ferguson 1951). The monthly rainfall ranges from $132 \mathrm{~mm}$ to 400 $\mathrm{mm}$ and the mean rainy days range from 4 days to 20 days. The soil of the area belongs to the litosol and red yellow podzolic categories (BPS Pasaman 2011). The study site was a hilly area in the northeast part of Simpati District.

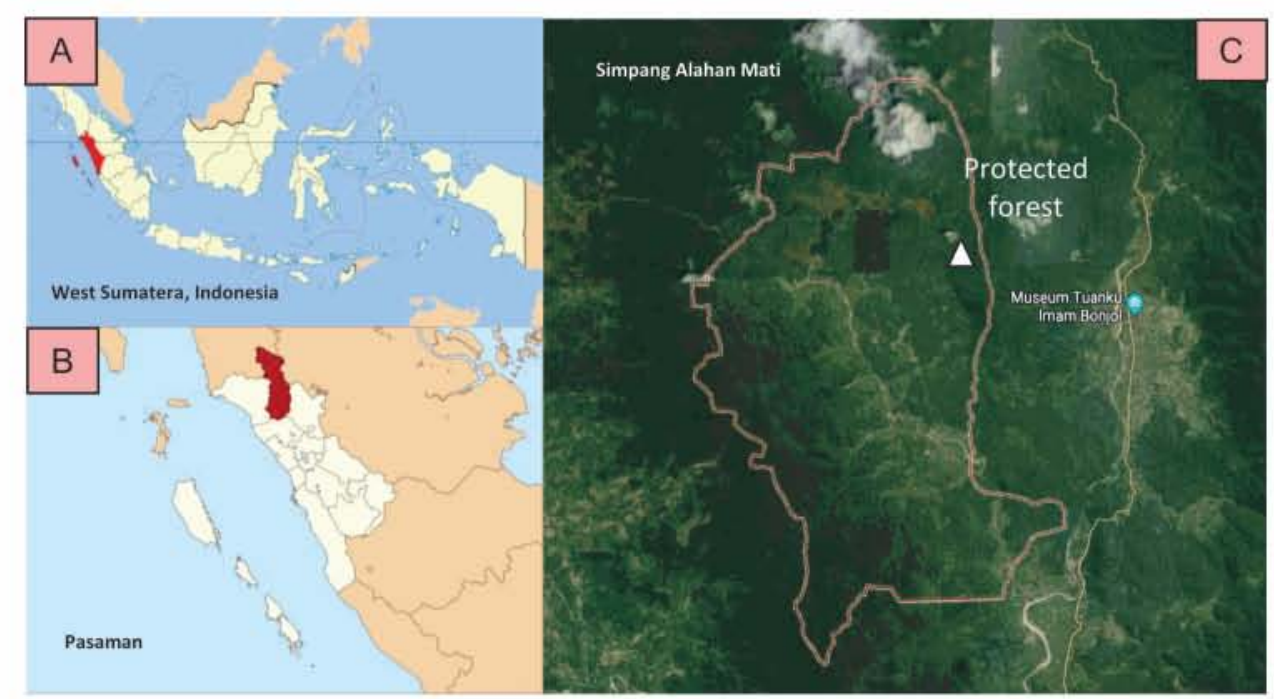

Figure 1 A. West Sumatera Province; B. Pasaman Region; C. Study site (Source: Google Maps 2018) 
Data collection was conducted using quadrat methods (Cox 1967; Mueller-Dombois \& Ellenberg 1974). The design and size of plot implemented in this study followed BSNI (2011) using normative references based on COP-15 Decisions on REDD + methodology guidance (Dec. 4/CP-15), IPCC 2006 Guidelines for National Greenhouse Gas Inventories and IPCC 2003 Good Practice Guidance for Land Use, Land Use Changes and Forestry, as this study was also aimed to estimate the Aboveground C-stock. A nested plot design of one hectare was established subjectively in the most accessible area of Bukit Badindiang. The plot was further divided into 25 trees and debris subplots of $20 \times 20 \mathrm{~m}$ each. The size of the plot and subplots were as follows: seedlings (woody tree species with leaves more than two strands and a height of $\leq 1.5 \mathrm{~m}$ ); understorey layer species (non-ligneous and ligneous herbs, ferns, shrubs and tree species with heights $<1.5 \mathrm{~m}$ ); and litter with a minimum area of $1 \mathrm{~m}^{2}$, saplings $(\mathrm{DBH}<10 \mathrm{~cm}$ and a height of $>1.5 \mathrm{~m})$ with a minimum area of $25 \mathrm{~m}^{2}$ and trees (DBH $\geq 10 \mathrm{~cm}$ ) and debris with a minimum area of $400 \mathrm{~m}^{2}$. (DBH $=$ Diameter at Breast Height).

\section{Samples Collection}

The entire tree individuals in the $400 \mathrm{~m}^{2}$ plot and saplings in $25 \mathrm{~m}^{2}$ plots were numbered and collected. DBH of all trees and saplings were measured. Seedlings and understorey layer species in the $1 \mathrm{~m}^{2}$ plot were all cut and mixed. Wet weight was measured. Then as many as $300 \mathrm{~g}$ of sample were taken to measure the dry weight. Litter was collected in $1 \mathrm{~m}^{2}$ subsize. All of the collected litters were filtered with a $2 \mathrm{~mm}$ sieve and then ovendried at $70{ }^{\circ} \mathrm{C}$ until reaching constant weight. To determine the biomass of debris, the diameter and the length of all debris in the $400 \mathrm{~m}^{2}$ plots were measured.

\section{Herbarium Specimen Collection and Identification}

Collected herbarium specimens of all species within the plots were identified at the Herbarium Bogoriense, Research Center for
Biology, LIPI in Cibinong, Indonesia. The identification and nomenclature of each tree species followed the Tree Flora of Indonesia: checklist for Sumatera (Whitmore \& Tantra 1986) and Flora Malesiana (Steenis et al. 19482013).

\section{Data Analysis}

The total of density, frequency, and dominance can be used to signify the importance of a species. It is expressed in terms of relative values. Relative Density (RD), Relative Frequency (FR) and Relative Dominance (RDo) were then calculated based on Cox (1967) and Mueller-Dombois and Ellenberg (1974). The index of species diversity $\left(H^{\prime}\right)$ was calculated by using Shannon-Wiener Index (SWI) (Shannon \& Wiener 1963). Species dominance (CD) was calculated following the index by Simpson (1949).

Aboveground C-Stock in one type of ecosystem or habitat is expressed in $\mathrm{Mg} / \mathrm{h}$. The total biomass in the plot $(\mathrm{Mg} / \mathrm{ha})$ is converted to $\mathrm{C}$-stock $(\mathrm{MgC} / \mathrm{ha})$. Aboveground biomass of tree was estimated by using specific allometric equation based on DBH. The allometric equations used in this study was developed by Ketterings et al. (2001) specifically for woody trees on Sumatera secondary forest. Also, debris biomass was calculated by using equation by Nascimento and Laurance (2002).

\section{RESULTS AND DISCUSSION}

\section{Species Composition and Structure}

In one hectare plot, there were 466 trees recorded, representing 139 species and 49 families with a total basal area of $38.59 \mathrm{~m}^{2}$. Each of 62 species (44.6\%) had only a density of one tree/ha (Fig 2). H' was 3.13 and species dominance (CD) was 0.64. Table 1 shows that Campnosperma auriculata, Ficus benjamina, Mallotus caudatus and Artocarpus lanceifolius were four most important species, with IV $>10$. 


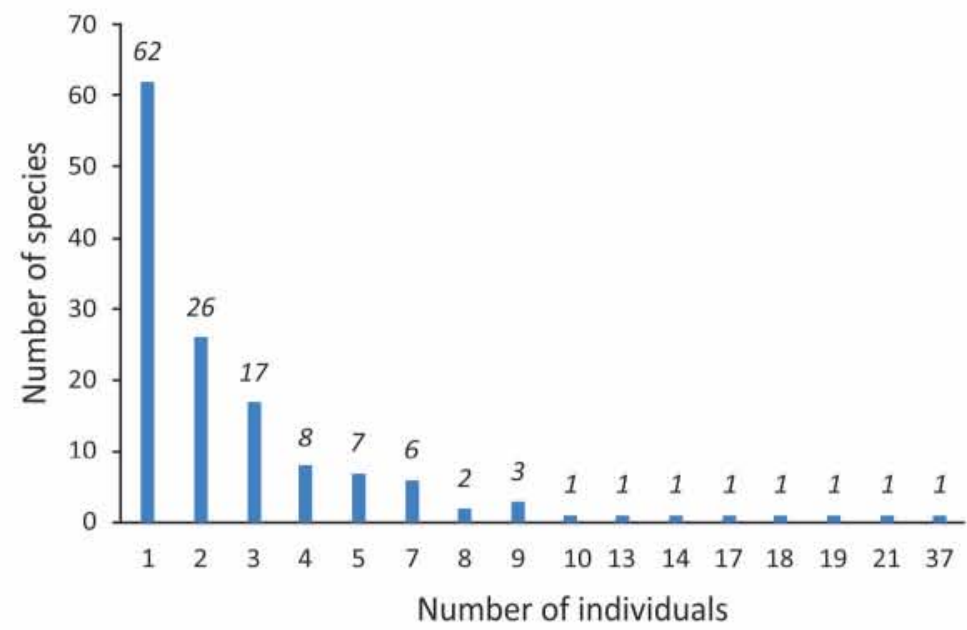

Figure 2 Number of species and number of individuals of trees in a one-hectare plot of forest in Simpang, Alahan Mati, West Sumatera Province.

Tabel 1 The Relative Density (RD), Relative Frequency (RF), Relative Dominance (RDo) and Importance Value (IV = $\mathrm{RD}+\mathrm{RF}+\mathrm{RDo}$ ) of the ten most important species based on IV

\begin{tabular}{cllcccc}
\hline No & \multicolumn{1}{c}{ Species } & Family & RD (\%) & RF (\%) & RDo (\%) & IV (\%) \\
\hline 1 & Campnosperma auriculata & Anacardiaceae & 4.08 & 1.98 & 13.14 & 19.19 \\
2 & Ficus benjamina & Moraceae & 0.86 & 1.13 & 14.51 & 16.50 \\
3 & Mallotus caudatus & Euphorbiaceae & 7.94 & 5.08 & 1.76 & 14.78 \\
4 & Artocarpus lanceifolius & Moraceae & 3.65 & 2.82 & 4.00 & 10.47 \\
5 & Sysygium nervosum & Myrtaceae & 4.51 & 3.67 & 1.24 & 9.42 \\
6 & Castanopsis tungurrut & Fagaceae & 2.79 & 1.98 & 3.35 & 8.12 \\
7 & Sysygium aqueum & Myrtaceae & 3.86 & 2.82 & 1.16 & 7.85 \\
8 & Quercus argentata & Fagaceae & 1.93 & 1.98 & 3.59 & 7.50 \\
9 & Mallotus mollissimus & Euphorbiaceae & 3.00 & 2.26 & 0.75 & 6.02 \\
10 & Reimwardtiodendron bumile & Meliaceae & 2.15 & 2.26 & 1.38 & 5.79 \\
\hline
\end{tabular}

Species density, dominance and distribution within plot varied. Nine out of ten species with the highest density were also species with the highest frequency, but they were in different orders (Table 2). M. caudatus had the highest density and frequency. There were only four species with $\mathrm{F}>30 \%$. Euphorbiaceae was the most important family followed by Anacardiaceae and Moraceae (Table 3).

Tabel 2 Ten species with highest frequency (F), density (D) and basal area (BA)

\begin{tabular}{|c|c|c|}
\hline & Species group & Species \\
\hline a & $\begin{array}{l}\text { Ten species with highest } \\
\text { density (number of } \\
\text { tress/ha) }\end{array}$ & $\begin{array}{l}\text { Mallotus caudatus (37), Syyggium nervosum (21), Campnosperma auriculata (19), Syzygium } \\
\text { aqueum (18), Artocarpus lanceifolius (17), Mallotus mollissimus (14), Castanopsis tungurrut } \\
\text { (13), Reinwardtiodendron bumile (10), Barringtonia conoidea (9), Meiogyne virgata (9) }\end{array}$ \\
\hline $\mathrm{b}$ & $\begin{array}{l}\text { Ten species with highest } \\
\text { frequency }(\%)\end{array}$ & $\begin{array}{l}\text { Mallotus caudatus (0.72), Syzygium nervosum (0.52), Artocarpus lanceifolius (0.4), Syzygium } \\
\text { aqueum }(0.4), \text { Mallotus mollissimus }(0.32) \text {, Reinwardtiodendron bumile }(0.32) \text {, Castanopsis } \\
\text { tungurrut }(0.28) \text {, Meiogyne virgata }(0.28) \text {, Quercus argentata }(0.28) \text {, Campnosperma } \\
\text { auriculata }(0.28)\end{array}$ \\
\hline c & $\begin{array}{l}\text { Ten species with highest } \\
\text { basal area }\left(\mathrm{m}^{2}\right)\end{array}$ & $\begin{array}{l}\text { Ficus benjamina (5.6), Campnosperma auriculata (5.27), Artocarpus lanceifolius (1.54), } \\
\text { Quercus argentata (1.39), Castanopsis tungurrut }(1.29) \text {, Antidesma leucopodum }(0.88) \text {, } \\
\text { Styrax benzoin (0.82), Mangifera foetida (0.8), Nepbelium juglandifolia }(0.79), \text { Mallotus } \\
\text { caudatus }(0.68)\end{array}$ \\
\hline $\mathrm{d}$ & $\begin{array}{l}\text { Ten species with highest } \\
\text { Importance Values (\%) }\end{array}$ & $\begin{array}{l}\text { Campnosperma auriculata (19.19), Ficus benjamina (16.5), Mallotus caudatus (14.78), } \\
\text { Artocarpus lanceifolius (10.47), Syzgium nervosum (9.42), Castanopsis tungurrut (8.12), } \\
\text { Syzygium aqueum (7.85), Quercus argentata (7.50), Mallotus mollissimus (6.02), } \\
\text { Reimwardtiodendron bumile (5.79) }\end{array}$ \\
\hline
\end{tabular}


Tabel 3 Summary of family characteristics at tree level

\begin{tabular}{ll}
\hline \multicolumn{1}{c}{ Characteristics } & \multicolumn{1}{c}{ Family } \\
\hline $\begin{array}{l}\text { Eleven families with number of } \\
\text { species } \geq 5\end{array}$ & $\begin{array}{l}\text { Euphorbiaceae (10), Lauraceae (10), Meliaceae (8), Malvaceae (7), Moraceae (7), } \\
\text { Myrtaceae (7), Dipterocarpaceae (6), Phyllanthaceae (6), Anacardiaceae (5), } \\
\text { Annonaceae (5), Fabaceae (5) }\end{array}$ \\
\hline $\begin{array}{l}\text { Ten families with highest } \\
\text { density (tress/ha) }\end{array}$ & $\begin{array}{l}\text { Euphorbiaceae (85), Myrtaceae (53), Anacardiaceae (42), Meliaceae (29), Moraceae } \\
(27), \text { Fagaceae (26), Lauraceae (25), Annonaceae (16), Malvaceae (16), Styraxaceae } \\
\end{array}$ \\
\hline Ten families with highest basal \\
area (m $\left.{ }^{2}\right)$
\end{tabular}
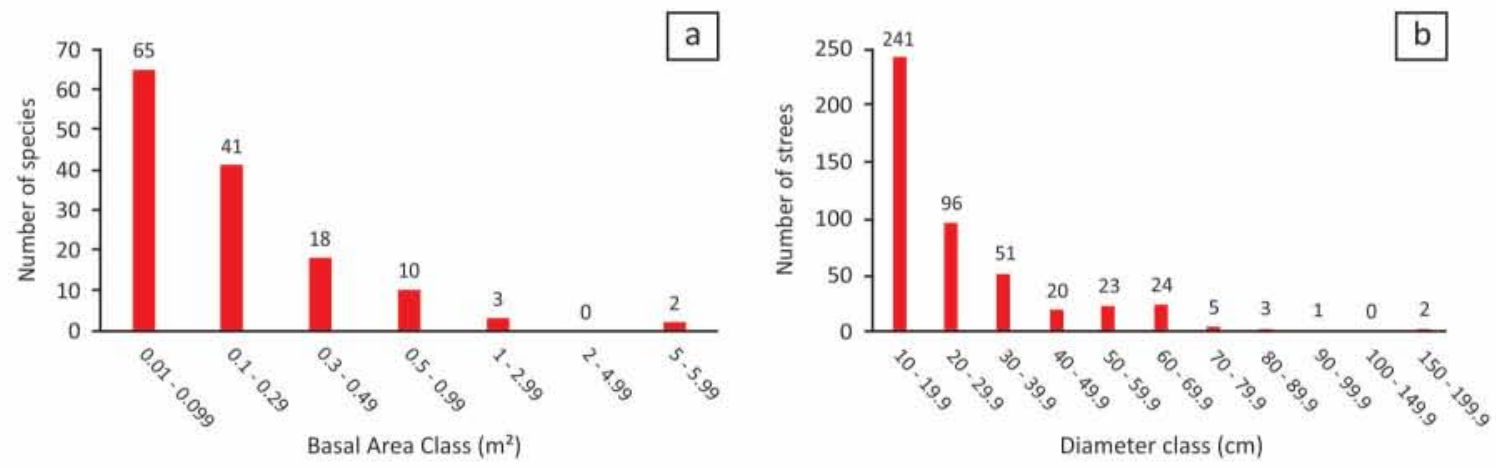

Figure 3 a. Number of species according to the BA classes and b. the number of trees according to the diameter classes

The total basal area for all species was $38.59 \mathrm{~m}^{2}$, with the mean BA of $0.28 \mathrm{~m}^{2}$. F. benjamina had the highest BA $(14.51 \%$ of the total). A total of 106 species $(76.3 \%)$ had BA of $<0.3 \mathrm{~m}^{2}$ (Fig. 3a). A high proportion of trees in the samples was represented by small individuals. Trees with DBH $<30 \mathrm{~cm}$ had the highest number, i.e., 377 individuals $(72.3 \%)$ (Fig. 3a).

This study represents an ecosystem of a lowland rainforest under the customary conservation sense in West Sumatera Province. It presents a collected data set systematically that can be compared to similar plot inventories of other tropical rainforests in Indonesia. Table 4 compares tree species diversity of this study with other natural forests in Sumatera. The species richness and tree density in customary forest of Nagari Simpang, Pasaman was higher than those in several lowland forests in Sumatera, but lower than one on Batang Gadis National Park (NP) North Sumatera, considering that the ecological status of Batang Gadis NP as undisturbed protected forest (Kartawinata et al. 2004).
Heretofore, the only other floristically quantitative description of natural forest in Pasaman was published by Yusuf et al. (2005) in Rimbo Panti. Tree density in this study was higher compared to Rimbo Panti. Lowland forest variations are related to terrain, topography, and degree of natural or anthropogenic disturbance. Tree density on the ridge is relatively higher than on the flat location while the basal area is lower (Whitmore 1986). The topography of Rimbo Panti forest was relatively flat compared to the steep Bukit Badindiang with average slope of $34.2^{\circ}$. Another factor is human pressure. It should be noted that although Rimbo Panti status was as a Nature Reserve, the forest was still experiencing the pressure from the human. There were still found some open canopy due to logging and replaced by secondary tree species such as Omalanthus populneus and Macaranga tanarius.

Species with the highest IV was $C$. auriculata. It is a mid-canopy tree in undisturbed mixed dipterocarp and freshwater swamp forests. Species in this genus are generally strongly light- 
demanding even when young, and regenerate more abundantly in more open or disturbed habitats. On the study site, they were found mostly on relatively flat spots on the top of the hill. It can be assumed that those species grew great in the past throughout the phase when canopy gaps were established in consequence of natural disturbances and human activities. The land-use histories of Bukit Bandindiang showed that before 1970 this forest was used to be a shortcut to get to Bonjol Subdistrict. Koto people planted many kinds of economically valuable trees such as Parkia speciosa, Durio ribentbinus, and Archidendron pauciflorum on the opened flat area. The existence of these trees is proof that some parts of this forest were disturbed.

Another interesting species highlighted is $M$. caudatus. Although it was only the third rank in terms of IV, these trees were recorded as species with the highest density and frequency on the sampling unit. It means that $M$. caudatus was the species with the highest number of individuals and could be evenly found on most plots at the same time. Generally, $M$. caudatus can be found on understorey of forest, riverine forest, kerangas forest, selectively logged forest, mainly on undulating to steep land and ridges of hills; soil yellow to brown sand or red clay. The fruiting and flowering seasons of it is throughout the year (Welzen \& Sierra 2006). It explains why this species could be easily found on the study site.

The higher value of the diversity indices represented the greater diversity and the abundance of tree species (Adekunle et al. 2013). SWI for tree species diversity in this study was 3.13. This values showed a relatively high number of tree species diversity based on the diversity index criterion by Soegianto (1994). There are sixty species or more than $40 \%$ of the total species found on the site had a density of one tree/ha. This number is relatively high compared to a similar study on Bukit Duabelas NP, Jambi that only have forty-four species (30\% of total species). This result was strongly related to the local wisdom that prohibits people to cut trees with low abundance. Furthermore, among sixty species recorded, there were five species included in the IUCN Red List, i.e., Aporusa sp., Lophopetalum wightianum, Parashorea lucida, Prunus arborea, and Xanthopbyllum sp.

The forest at the family level was dominated by Euphorbiaceae. The result is similar to the prior study conducted at Rimbo Panti. In the tropical region, the family of Euphorbiaceae is found to be superior to other families in most cases, especially in disturbed forest. Species on this family are known to have good adaptability to any type of forest (Whitmore 1989). Another interesting family is Dipterocarpaceae. Despite a low number of individuals found on the site, Dipterocarpaceae was on top ten families with the highest IV because of their averagely wide basal area. The two most significant species of Dipterocarpaceae found were Dipterocarpus baudii and Shorea hopeifolia. Both are included in IUCN Red List as Vulnerable and Critically Endangered criteria, respectively.

The forest investigated in this study was characterized by a high abundance of small trees with $\mathrm{DBH}<30 \mathrm{~cm}$. This result is similar to other disturbed forests in Sumatera (Yusuf et al. 2005; Hadi et al. 2009; Rahmah et al. 2016). The relatively small number of large trees can be explained by two main causes. There was a possibility that there might be a restricted number of species that authentically matured to these diameters (Hartshorn 1980) and their seedlings require to meet optimal circumstances of environment or locations for growth, to outcompete other species, the fast-growing one particularly. Another cause was the abundance of certain big tree species (i.e., Dipterocarpaceae) could have been already reduced by selective logging for human needs. As the timber harvesting in Bukit Badindiang was restricted to only a few concerns, we consider natural causes also to play a significant role in restricting the number of big trees in our study area. This assumption is based on the existence of fallen decaying big trees on the forest floor and tree stumps and other wood remains resulting from natural cutting. It is also shown in relatively high percentage of estimated debris biomass found on the plots (Table 5). 
Tabel 4 Comparison tree diversity in several natural forest in Sumatera

\begin{tabular}{|c|c|c|c|c|c|c|c|}
\hline No & Locality & Methods & $\begin{array}{l}\text { Area of } \\
\text { plot (ha) }\end{array}$ & $\begin{array}{l}\text { Number } \\
\text { of trees }\end{array}$ & $\begin{array}{l}\text { Number } \\
\text { of species }\end{array}$ & $\begin{array}{l}\text { Number } \\
\text { of families }\end{array}$ & Source \\
\hline 1 & $\begin{array}{l}\text { West Sumatera Province } \\
\text { Nagari Simpang, Pasaman, } \\
\text { West Sumatera Province }\end{array}$ & Quadrat & 1 & 466 & 139 & 49 & Present study \\
\hline 2 & $\begin{array}{l}\text { Rimbo Panti Natural Forest, } \\
\text { Pasaman, West Sumatera } \\
\text { Province }\end{array}$ & Quadrat & 1 & 323 & 114 & 41 & $\begin{array}{l}\text { Yusuf et al. } \\
(2005)\end{array}$ \\
\hline 3 & $\begin{array}{l}\text { Siberut, West Sumatera } \\
\text { Province } \\
\text { Other forest on Sumatera }\end{array}$ & $\begin{array}{l}\text { Belt } \\
\text { Transect }\end{array}$ & 1.36 & 207 & 139 & 35 & Hadi et al. (2009) \\
\hline 4 & Hutan Adat Kampar, Riau & $\begin{array}{l}\text { Belt } \\
\text { Transect }\end{array}$ & 0.4 & 227 & 135 & 38 & Remina (2017) \\
\hline 5 & Bukit Duabelas NP, Jambi & Quadrat & 1 & 414 & 113 & 38 & $\begin{array}{l}\text { Rahmah et al. } \\
\text { (2016) }\end{array}$ \\
\hline 6 & $\begin{array}{l}\text { Mt. Leuser NP, North } \\
\text { Sumatera }\end{array}$ & Quadrat & 1 & 687 & 110 & 34 & $\begin{array}{l}\text { Samsoedin \& } \\
\text { Heriyanto (2010) }\end{array}$ \\
\hline 7 & $\begin{array}{l}\text { Batang Gadis NP, North } \\
\text { Sumatera }\end{array}$ & Quadrat & 1 & 583 & 205 & 41 & $\begin{array}{l}\text { Kartawinata et al. } \\
(2004)\end{array}$ \\
\hline
\end{tabular}

\section{Aboveground C-Stock}

The total Aboveground C-Stock estimated was $190.62 \mathrm{MgC} / \mathrm{ha}$ (Table 5), with the highest $\mathrm{C}$ was contributed by trees. $F$. benjamina, C. auriculata and $A$. lanceifolius were the top three species that contributed C $(44.6 \%$ of total carbon from trees). Tree diameter class of 150 $199.9 \mathrm{~cm}$ stored the highest amount of carbon (42.54 MgC/ha) (Fig 4). Tree with diameter class of $60-69.99 \mathrm{~cm}$ placed the second rank with CStock of $39.04 \mathrm{MgC} / \mathrm{ha}$. This class was filled by 14 species from a varied family with a dominant C accumulator was $C$. auriculata. It accumulated nearly $33 \%$ of total C-Stock in that class. Trees with a diameter class of $10-69.99 \mathrm{~cm}$ stored
$62 \%$ of total tree carbon in a hectare, followed by trees with a diameter class of $150-199.99 \mathrm{~cm}$ $(24 \%)$ and $70-100 \mathrm{~cm}(14 \%)$.

Tabel 5 Summary of total Aboveground C-Stock based on carbon pool

\begin{tabular}{lcc}
\hline Carbon pool & $\begin{array}{c}\text { Total Tree } \\
\text { Biomass } \\
(\mathrm{Mg} / \mathrm{ha})\end{array}$ & $\begin{array}{c}\text { Total Carbon } \\
\text { Biomass }(\mathrm{MgC} / \mathrm{ha})\end{array}$ \\
\hline Tree & 357.70 & 178.85 \\
Sapling & 5.72 & 2.86 \\
Seedling & 0.46 & 0.23 \\
Litter & 1.24 & 0.62 \\
Debris & 16.13 & 8.07 \\
\hline \multicolumn{1}{c}{ Total } & 381.25 & 190.62 \\
\hline
\end{tabular}

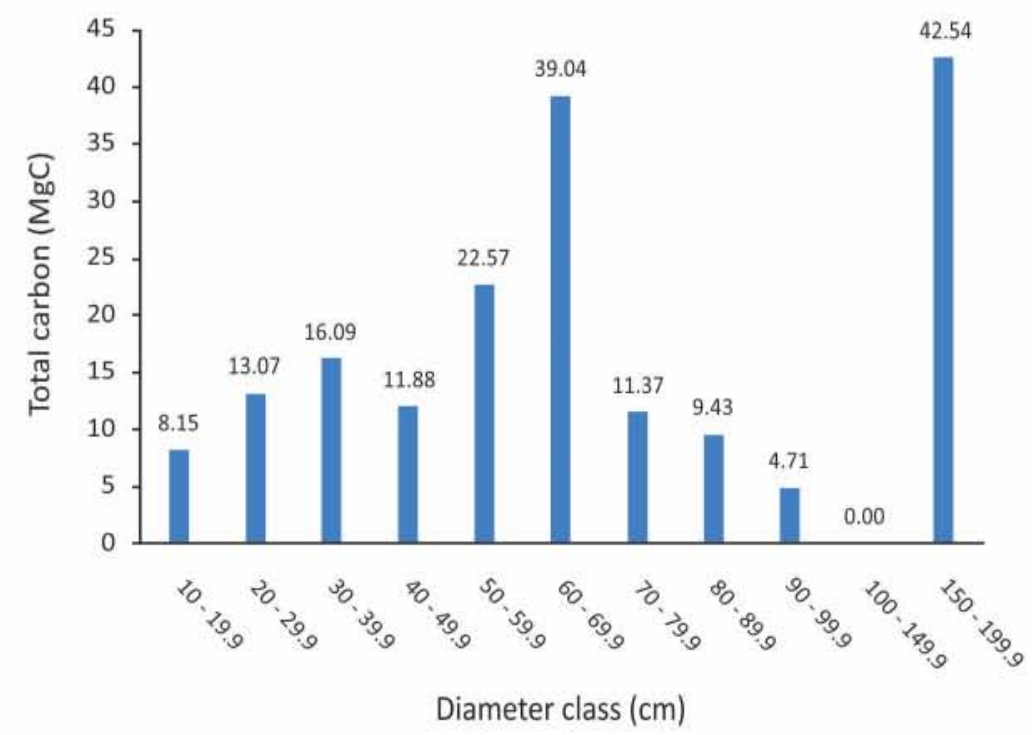

Figure 4 Distribution of tree carbon biomass based on diameter class 
Estimated $\mathrm{C}$ pools in several forest types can be referred to in taking decisions about $\mathrm{C}$ management within forests. Parameters to measure the carbon dioxide binding level on a type of land-use are tree biomass $(\mathrm{Mg} / \mathrm{ha})$ and carbon biomass $(\mathrm{MgC} / \mathrm{ha})$. It was estimated that the sacred forest of Nagari Simpang Pasaman stored $190.62 \mathrm{MgC} / \mathrm{ha}$. The value estimated on this study is relatively comparable to other CStock assessment of Sumatera natural forest. van Noordwijk et al. (2002) assessed secondary forests in Sumber Jaya, Lampung with an average estimated carbon of 195 $\mathrm{MgC} /$ ha. Laumonier et al. (2010) have also estimated aboveground C-Stock land-scape of several dipterocarp forests of Sumatera, amounting $180.5 \mathrm{Mg} / \mathrm{ha}$ (ranging between 270 $480 \mathrm{Mg} / \mathrm{ha}$ ).

The forest can act as a source and a sink based on the level of succession, specific type disturbance, or level of human intervention (Masera et al. 2003). On this study site, the small to medium trees contributed more $\mathrm{AGB}$ than large trees. $62 \%$ of carbon was stored by trees with diameter class of $10-69.99 \mathrm{~cm}$. As on this stage, the tree grow vigorously, accordingly with the prompt accumulation of C-stock. However, the conservation of mature large trees with diameter $>150 \mathrm{~cm}$ is highly suggested considering $24 \%$ of carbon on this forest was accumulated on these trees.

Bukit Badindiang forest is preserved by local communities for conservation and religious purpose. Local government established Bukit Badindiang as a customary forest. The result of this study can serve as a baseline for the implementation of carbon-based project activities. Community-based sacred conservation management of this forest attempts to avoid deforestation and encroachment. Forest area on this district is under severe threat from the construction of gold mining projects. The surrounding community depends on forests mostly to meet their needs for timber and nontimber forest products. Conservation of Bukit Badindiang forest will lead to increased exploitation of surrounding unprotected forests if conservation strategies are not proceed and implemented in those areas.

\section{CONCLUSION}

In one hectare plot, we recorded 466 trees, representing 139 species and 49 families with a total basal area of $38.59 \mathrm{~m}^{2}$ with estimated Aboveground C-Stock of $190.62 \mathrm{MgC} / \mathrm{ha}$. It can be concluded that the sacred forest of Bukit Badindiang was a disturbed forest structurally and floristically with heterogeneous species composition. It is reflected by low frequency and density of the species. The species richness and tree density were relatively higher than those in several other disturbed lowland forests of Sumatera. The mixed composition of the forest studied provides numerous important ecological niches and emphasizes the outstanding contribution of this forest to the biodiversity of the region. Bukit Badindiang forest can provide models for sustainable utilization of forest resources in the region. Further research on structure and composition of forests of other community-based conservation over a more comprehensive area in the region are needed.

\section{ACKNOWLEDGEMENTS}

This study has been supported by a grant from Kemristek DIKTI. Thanks to Keltan and Gapoktan member and staff in both Pasaman and Padang Pariaman for the access and permit to make plots and to the following people for field data collection and analysis: Erna, Robi, Nita, Aldo and Isul. We also thank Universitas Negeri Padang for providing some tools used during fieldworks.

\section{REFERENCES}

Adekunle VAJ, Olagoke AO, Akinele SO. 2013. Tree species diversity and structure of a Nigerian strict nature reserve. Tropical Ecology 54:275-89.

Allendorf TD, Yang J. 2013. The role of ecosystem services in park-people relationships: the case of Gaoligongshan Nature Reserve in southwest China. Biol Conserv 167:187-93.

Badan Pusat Statistik (BPS) Pasaman. 2011. Statistic of Simpang Alahan Mati Subdistrict. Available from: https://pasamankab.bps.go.id/publication.html accessed February 14, 2018 [Indonesia]. 
Badan Standar Nasional Indonesia (BSNI). 2011 Measurement and calculation of C-stocks field measurements for forest $\mathrm{C}$-stock estimation (ground-based forest carbon accounting). Jakarta (ID): BSN. [Indonesian].

Balai Penelitian Kehutanan (BPK) Aek Nauli. 2012 Working report: development of Permanent Sampling Plot (PSP) as an effort to provide data and monitoring of $\mathrm{C}$-stock and $\mathrm{C}$-stock changes in different types of forest cover in Costumary Forest (Hutan Nagari), West Sumatera Province. Bogor (ID): Puspijak of Indonesia Forestry Ministry. [Indonesian].

Basu R. 2000. Studies on sacred groves and taboos in Purulia District of West Bengal. Indian Forester 126:1309-18.

Boedhihartono AK. 2017. Can community forests be compatible with biodiversity conservation in Indonesia? Land 21(6):1-17.

Boraiah KT, Vasudeva R., Bhagwat SA, Kushalappa CG. 2003. Do informally managed sacred groves have higher richness and regeneration of medicinal plants than state-managed reserve forests? Current Science 84(6):804-8.

Brown S. 1997. Estimating biomass and biomass change of tropical forests: a primer. FAO Forestry Paper No. 134. Roma (IT): FAO.

Burman Y J R. 2003. Sacred Groves Among Communities: The Mahadeo Kolis and the Kunbis of the Western Ghats. New Delhi (IN): Mittal.

Chandran MDS, Hughes JD. 1997. The sacred groves of south India: ecology, traditional communities and religious change. Social Compass 44:413-28.

Christiawan PI. 2015. The role of local wisdom in controlling deforestation. Int J Dev Sustain 6(8):876-88.

Cox WG. 1967. Laboratory manual of general ecology. Dubuque (FR): Wm. C. Brown Company Publisher.

Hadi S, Ziegler T, Waltert M, Hodges K. 2009. Tree diversity and forest structure in northern Siberut, Mentawai Islands, Indonesia. Tropical Ecology 50(2):315-27.

Hartshorn GS. 1980. Neotropical forest dynamics. Biotropica 12:23-30.

Indrajaya Y. 2013. C-Stocks of Protection Forest in Malinau District, East Kalimantan to Support REDD+ Mechanism. Jurnal Penelitian Sosial dan Ekonomi Kehutanan 10(2):99-109 [Indonesian].

Kartawinata K. 1994. The use of secondary forest species in rehabilitation of degraded forest lands. J Trop For Sci 7(1):76-86.

Kettering QM, Coe R, van Noordwijk M. 2001. Reducing uncertainty in the use of allometric biomass equations for predicting above-ground tree biomass in mixed secondary forests. For Ecol Manag 120:199-209.

Laumonier Y, Edin A, Kanninen M, Munandar AW. 2010. Landscape-scale variation in the structure and biomass of the hill dipterocarp forest of Sumatera: Implications for C-stock assessments. For Ecol Manag 259:505-13.

Masera OR, Garza-Caligaris JF, Kanninen M, Karjalainen T, Liski J, Nabuurs GJ, Passinen A, de Jong BHJ, Mohren GMJ. 2003. Modelling carbon equestration in afforestation, agroforestry and forest management projects: the CO2 FIXV.2 approach. Ecol Model 164:177-99.

Mueller-Dombois D, Ellenberg H. 1974. Aims and method of vegetation ecology. New York (US): John Wiley \& Sons.

Nascimento HEM, Laurance WF. 2002. Total AGB in central Amazonian rainforests: a landscape-scale study. For Ecol Manag 168:311-21.

Negi CS. 2015. Developing sacred forests into biodiveristy heritage sites-experiences from the state of Uttarakhand, Central Himalaya, India. Indian J Tradition Knowl 1(1):96-102.

Ormsby AA, Bhagwat S. 2010. Sacred forests in India: a strong tradition of community based natural resource management. Environ Conserv 37(3):32026.

Pala NA, Negi AK, Gokhale Y, Aziem S, Vikrant, KK, Todaria NP. 2012. C-stock estimation for tree species of Sem Mukhem sacred forest in Garhwal Himalaya, India. J For Res 24(3):457-60.

Pradhan A, Mishra SP, Behera N. 2016. Species diversity and biomass carbon analysis of the tree layer in a sacred natural forest patch from Western Odisha. Int J Enviro Sci 7(2):113-22.

Rahmah, Kartawinata K, Nisyawati, Wardhana W, Nurdin E. 2016. Tree species diversity in the lowland forest of the core zone of the Bukit Dua Belas National Park, Jambi, Indonesia. Reindwardtia 15(1):11-26,

Remina D. 2017. Vegetation analysis and C-Stock Estimation in Kampar Costumary Natural Park, Kampar District Riau. [Thesis]. Padang (ID): Universitas Andalas. [Indonesian].

Samsoedin I, Heriyanto NM. 2010. Structure and composition of illegal logged secondary forest in the Sei Lepan forest group, Sei Serdang, Gunung Leuser National Park, North Sumatra. Jurnal Penelitian Hutan dan Konservasi Alam 7:299-314 [Indonesian].

Schmidt FH, Ferguson JH. 1951. Rainfall types based on wet and dry period rations for Indonesia with Western New Guinea. Jakarta (ID): Verhandelingen Djawatan Meteorologi dan Geofisika.p.42. 
Shannon CE, Wiener W. 1963. The Mathematical Theory of Communication. Urbana (US): University of Illinois Press.

Simpson EH. 1949. Measurement of Diversity. Nature 163:688.

Sinha RK. 1995. Biodiversity conservation through faith and tradition in India: Some case studies. Int J Sustain Develop World Ecol 2:278-84.

Soegianto A. 1994. Quantitative ecology: Population and community analysis methods. Surabaya (ID): Usaha Nasional. [Indonesian].

Soendjoto MA, Suyanto, Hafiziannoor, Purnama A, Rafiqi A, Sjukran. 2009. Plants diversity of farm forestry in Tanah Laut District, South Kalimantan. Biodiversitas 9(2):142-7.

Steenis CGG, Van J, Kalkman C, Kirkup DW, Noteboom HP, de Wilde WJJO, Saw LG, Stevens PF, Coode MJE,van Welzen PC (Eds.). 1948-2013. Flora Malesiana Series I, Vol. 4-21. Leiden (NL): Foundation Flora Malesiana.
vanNoordwijk M, Rahayu S, Hairiah K, Wulan YC, Farida A, Verbist B. 2002. C-stock assessment for a forest-to-coffee conversion landscape in SumberJaya (Lampung, Indonesia): from allometric equations to land use change analysis. Sci China 45:75-86.

Wadley RL, Colfer CJP. 2004. Sacred forest, hunting, and conservation in West Kalimantan, Indonesia. Human ecology 32(3):313-38.

Welzen PC van, Sierra SEC. 2006. The Mallotus wrayi complex (Euphorbiaceae). Blumea 51:373-88.

Whitmore TC, Tantra IGM. 1986. Tree flora of Indonesia. Check list for Sumatera. Bogor (ID): Forest Research and Development Centre.

Whitmore TC. 1989. Southeast Asian tropical forests. In: Lieth $\mathrm{H}$, Werger MJH (eds.). Ecosystems of the World 14B, Tropical Rain Forest Ecosystems. Amsterdam (NL): Elsevier.

Yusuf R, Purwaningsih, Gusman. 2005. Composition and vegetation structure of Rimbo Panti natural forest, West Sumatera. Biodiversitas 6:266-71. [Indonesian]. 